\title{
HEVES MEGYE MEZŐGAZDASÁGA, KERTGAZDÁLKODÁSA
}

\author{
Kaprinyák Tünde
}

\section{Összefoglalás}

Az urbanizáció terjedésével az emberek számára mind fontosabbá válik az egészséges táplálkozás, melynek. fontos

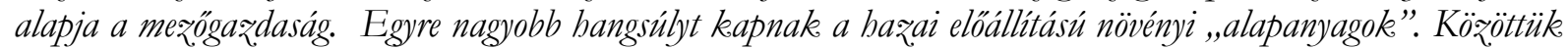
vannak olyan növények, amelyek kialakulása, termesztése csak egy-egy termötájhoz, kötödik. Ezen területek. a genetikai variabilitás megörzésében is szerepet játszanak.

A klímaváltozás által elöidézett negativ körmyezeti hatások a mérsékelt égörben is súlyos károkat okoznak. A termesztökörzetek eltolódnak; új kórokozók, kártevők képesek nálunk életfeltételeiket megtalálni. Megoldási lehetöség lehet a hazai, történelmi fajták ismételt bevonása üjra a termesztésbe. A bungarikumok között egyre több hazai növényi termék található. A fajok biológiai és genetikai alapjainak szélesitése, a hagyomány megörzése ugyanolyan fontos, mint a kertészeti innováció. Heves megye változatos földrajzi adottságai miatt a męógazdaság (ezen belül a kertészet) hagyománya hosszú régmúltra nyúlik vissza. Sok, itt éló ember számára megélhetést nyújt közvetlenül a gyümölcs-, zöldségféléke elóállitása, és a bozzá kapcsolódó turizmus is.

Kulcsszavak: Heves megye, kertészet, hungarikum, hagyomány, jövő

JEL:Q57

\section{AGRICULTURE, HORTICULTURE IN HEVES COUNTY}

\begin{abstract}
With the spread of urbanization, the healthy nutrition, of which agriculture is an important basis, is becoming more and more important for people. There is an increasing emphasis on domestically produced plant "raw materials". Among them, there are some plants, the formation and cultivation are connected to only one-one growing region. These areas also play a role in preserving genetic variability.

The negative environmental impacts caused by climate change are also causing severe damage in the temperate zone. The growing areas are shifting, new pathogens and pests are able to find their habitat there. A possible solution could be to reintroduce domestic, historical varieties into cultivation again. Among the Hungaricums more and more domestic plant products can be found. The broadening the biological and genetic bases of species, the preserving tradition, is as important as the horticultural innovation. Due to the diverse geographical features of Heves county, the tradition of agriculture (including horticulture) dates back a long time. For many people living here, the growing of fruits and vegetables and related tourism also provide a livelihood.
\end{abstract}

Keywords: Heves county, horticulture, bungaricum, tradition, future JEL:Q57 


\section{Bevezetés}

A 121 db települést tömörítő, 300 ezer fölötti lélekszámú lakosú Heves megye 3637,25km² területén a termelési tájak találkozási vonalánál (vásári vonal) három nagy történelmi város: Eger, Gyöngyös és Hatvan helyezkedik el. Természeti- és tájföldrajzi adottságainál fogva a megyére földrajzi változatosság jellemző. Az Északi-középhegység és az Alföld nagytájakhoz egyaránt kapcsolódik, legmagasabb pontja egyúttal az ország legmagasabbja is (Kékes 1014 m). E két nagytáj találkozási pontjánál található változatos és kiemelkedő természeti értékek, adottságok kedvezőek a mezőgazdasági termelésnek, kertészeten belül a zöldség-, gyümölcs- és szőlőtermesztésnek (Baros et al. 2012; Internet1; Internet2)

\section{Anyag és módszer}

Domborzati adottságai miatt Heves megyében a hazai mezőgazdaság összes ágazata jelen van, viszont az eltérő talajadottságok miatt a terméshozamok az országosnál kisebbek. Az ipar mellett a szolgáltató ágazatok közül a kereskedelem játszik fontos szerepet a megyében (Bujdosó Remenyik, 2009). Három flórajárása közül a Matricum önálló. A megyében 32 féle genetikai talajtípust írtak le, ezek közül legnagyobb felületen a barna erdőtalajok és a folyók melletti öntéstalajok uralkodnak, kisebb foltokban a szikesek, csernozjom, löszös és homoktalajok is előfordulnak. A korai termesztésre kevésbé alkalmas a régió éghajlata miatt. Az alacsonyabb évi középhőmérsékletet és napfényes órák számát némileg enyhíti a Mátra hegyvonulata, ebből adódóan az enyhén déli lejtésű helyeken a talaj az alföldi területektől is jobban felmelegszik. Az éves csapadékmennyiség a tengerszint feletti magasság alapján alakul. Síkvidéki területeken 500-600 mm, felfelé haladva azonban ettől átlagosan 100-200 mm-rel több hullik le. A jégesők előfordulásának gyakorisága magas. A tenyészidőszakban lehulló kevés csapadék miatt a kertészeti termesztésre hasznosított területeken szükséges a vízpótló öntözés. Kertészeti növények előállítására főként a mezőségi vályogtalajok hasznosítottak (Markos, 1962; Internet3).

A tanulmány során szekunder forrásokból kerül bemutatásra Heves megye kertgazdálkodása, annak kialakulása és jelenlegi helyzete, kiemelve annak fontos elemeit, amelyek a megye gazdasági élete szempontjából jelentősek.

\section{Eredmények}

\section{Heves megye mezógazdasága}

A 18. század végéig Heves megyében a kertművelés elenyésző szerepű volt, északi részén nagy felületen terültek el az ártéri erdők, főként a füzesek, majd a lecsapolással itt is elindult a növénytermesztés, kertgazdálkodás (Dóka, 1982; Dóka, 1996).

Földrajzi elhelyezkedése miatt ma sem tartozik Heves megye a legnagyobb növénytermesztő és állattenyésztő megyék közé. Kiemelendő a térség szőlőtermesztése és borászati tevékenysége (Somos, 1973). Magasabban fekvő területeinek mikroklímája a déli oldalakon a sok napbesugárzásától egyedi, mely lehetôvé teszi a domb- és hegyvidéki borszőlőtermesztés kultúrájának megteremtését és fenntartását. Korábban a kisebb földterülettel (0-1 ha) rendelkezők szőlő- és kertművelésből tartották fenn magukat, míg a nagyobb birtokosok kizárólag szőlőtermesztésből, borértékesítésből szerezték éves bevételüket. Két történelmi borvidéke a Mátrai és az Egri borvidék, ahol ősszel nagy népszerűségnek örvendenek a szüreti mulatságok és kóstoltató programok. Évközben pedig a borkörutak vonzzák a turistákat a természeti látnivalók mellett. A két borvidék központjának tekintett Gyöngyös és Eger „A szőlő és bor városa” címet 
viseli. Hazánk második legnagyobb borvidéke a Mátrai borvidék, ôt követi a rangsorban az Egri borvidék.

\section{A Felsó-magyarországi borrégió jellemzői}

A szőlőterületek több mint 80\%-a egyéni gazdaságok tulajdonában van. Az 1800-as évek végén a filoxéravész nagy veszteséget jelentett a szőlőtermesztésben, aztán szép lassan újratelepítették vagy helyére különféle gyümölcstermő növényeket ültettek (pl. mandula, cseresznye). Értékes szőlőfajták génbanki gyüjteménye található Egerben (1. kép). Az Egri és a Mátrai borvidéken jelenleg engedélyezettek szőlőfajták közül kerül felsorolásra néhány:

- Vörösbor szőlőfajták: Blauburger, Cabernet franc, Cabernet sauvignon, Kadarka, Kékfrankos, Kadarka, Pinot noir, Merlot, Zweigelt, Turán, Syrah

- Fehérbor szőlőfajták: Cserszegi füszeres, Chardonnay, Chasselas, Furmint, Leányka, Olasz rizling, Sárga muskotály, Sauvignon, Zenit, Rajnai rizling, Pinot blanc, Rizlingszilváni, Zöld veltelini, Irsai Olivér (Internet12)

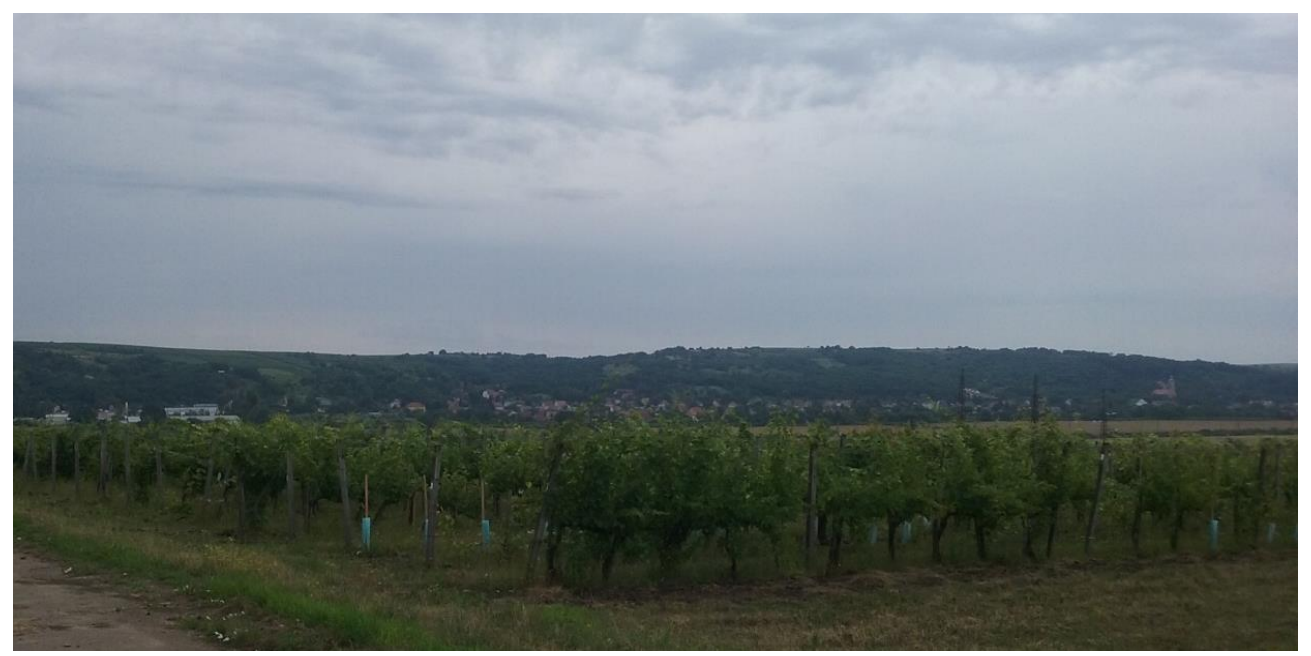

1. kép Az Eszterházy Károly Egyetem, Szőlészeti és Borászati Kutató Intézet génbankja Forrás: Kaprinyák, Eger, 2017

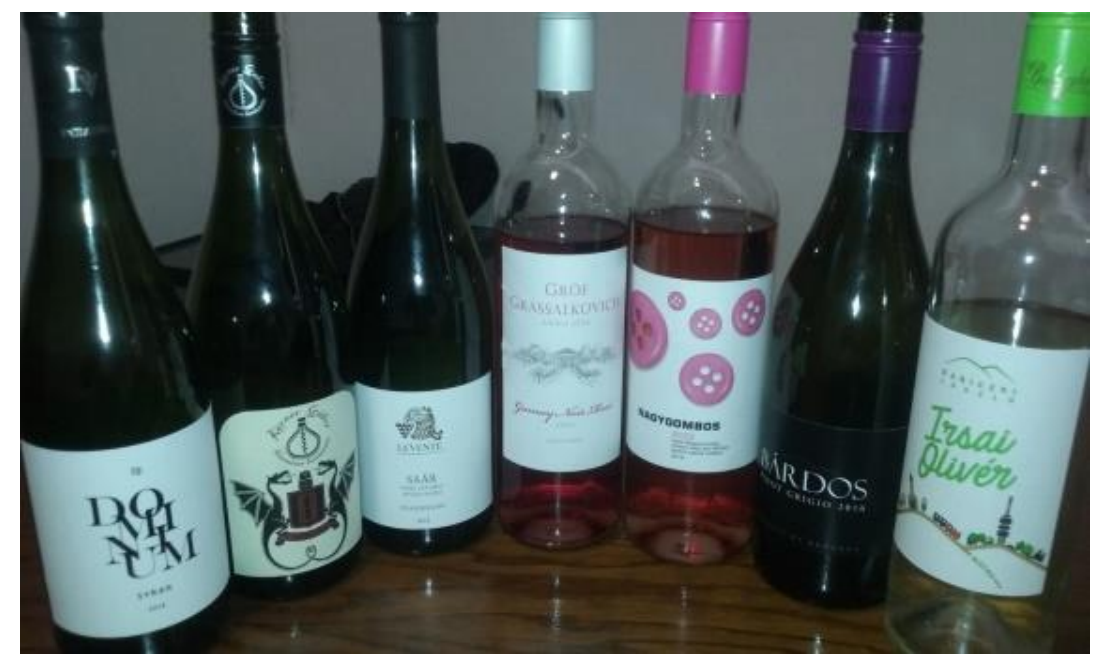

2. kép. Mátrai borok

Forrás: Kaprinyák, KRF Borklub borkóstoló, Gyöngyös, 2017 


\section{Heves megye kertgazdálkodása}

A szőlőtermesztés mellett a gyümölcstermesztés hagyományai is a régmúltig nyúlnak vissza Heves megyében (Kozári, 1988). A Kárpát-medence kedvező ökológiai és természeti adottságai miatt több évszázados múltra tekint vissza a gyümölcstermesztés. A mezőgazdasági termesztés sikerességét az adott növényfaj optimálishoz közeli környezeti igényeinek megléte és a gazdasági, társadalmi hatások döntő mértékben meghatározzák (Mohácsy-Maliga, 1956; Brózik, 1959; Surányi, 2011). Az itt élők számára a gyümölcsfajok széles választéka fôként saját igényeik kielégítését szolgálta, a fellelhető adatok szerint korábban a megye egyes területei jelentősek voltak a gazdaságos gyümölcstermesztésben. 1923-ban Heves megye alispánja a megye „elsőrendű gyümölcstermesztésére" utalva fontos óvintézkedéseket ajánlott járványveszély megjelenése miatt: törzstisztítás, szakszerű metszés, koronaritkítás, fák környékén őszi felszántás, lehullott lomb elégetése és permetezés. Egyúttal felkérte a községeket a gyümölcsfa-állomány összeírására (Internet6). A Mátrában szórványosan vadkörte, vadalma, ritkán somfa már korábban említett gyümölcsfélék. A kisebb növésű cserjék közül a mogyoró, kökény, vadszeder, málna, mint vadon termő gyümölcs szerepelt. Utóbbi a környéken élők számára jelentett és jelent ma is bevételi forrást, valamint táplálékot. Emellett a bőven termő „szamócza” terméseit a budapesti kofák szállították vasúton a fôvárosba értékesítésre. A filoxéravészt követôen a szőlő újratelepítés mellett korabeli irodalmi források említik, hogy a gyümölcstermesztés Eger és Gyöngyös környékén kiemelkedő, messze híres volt az egri körte és őszibarack. Az 1800-as évek végén a szőlészeti és kertészeti tanfolyamok mellett egy leírás az egri zöldségtermesztés fontosságát emeli ki. Az első összefüggő, nagyobb felületű gyümölcsösök az 1920-as évektôl létesültek, de az exportorientált, üzemi gyümölcstermesztés alapjai az 1960-70-es évekre tehetőek Heves megyében is. 1988-ban a kertgazdálkodás virágkorát élve további fejlesztést, képzéseket sürgettek a szakemberek. Heves megye a cseresznyetermesztés legrégebbi termesztőtája, Eger, Gyöngyös, Hatvan és Noszvaj környékén (Mohácsy - Maliga, 1956; Brózik, 1959; Surányi, 2011). A feketecseresznyék közül kiemelendő a Szomolyai fekete cseresznye (3. kép). A meggytermesztésben mára kisebb felület jellemzi a térséget. A baracktermesztésben a kajszi mellett az ôszibarack is megjelenik, utóbbi dombvidéki területeken (Nyujtó-Surányi, 1981; Surányi, 2011). A mandula Eger, Gyöngyös környékén termesztett gyümölcsfaj, amelyet perspektivikus kultúrnövényként említenek gyümölcskutatóink (Mohácsy - Magyar, 1936; Mohácsy - Porpáczy, 1951; Okályi, 1954; Mohácsy et al. 1957; Szentiványi et al. 1976; Brózik et al. 2003; Surányi, 2011). A bogyósok közül növekvő termesztőfelület volt jellemző a szamócára (Surányi; 2011), azonban az utóbbi években stagnál. Legnagyobb felületen az alma, körte, meggy, cseresznye, kajszibarack, szilva a termesztett gyümölcsfajok. Gyümölcstermesztő körzetek Csány, Eger, Hatvan, Heves, Gyöngyös, Kál, Recsk térségekben alakultak ki. Az 1900-as évek elején a filoxéra által kipusztított szőlőterületeken a fehér és piros ribiszke is termesztett növény lett. Szintén a filoxéravész után nőtt meg a termőterülete a köszmétének, bár korábban honos fajként már jelen volt. Később tájfajtái is kialakultak Gyöngyös térségében (Mohácsy - Porpáczy, 1952; Mohácsy - Maliga, 1956; Brózik, 1960; Harmat, 1987; Papp - Porpáczy, 1999; Surányi, 2011). Csipkebogyó betakarításról tesz említést a Népszava 1963-as kiadása, a begyújtött termés exportként került értékesítésre (Internet7). Heves megye megművelhető területe jelenleg is igen nagy, kb. 365000 hektáron folyik mezőgazdasági tevékenység. A gyümölcsös 4,6 ezer hektár, míg a szőlőterület 10,8 ezer hektár a teljes területből. A meggy, szilva és a cseresznye még mindig fontos a termesztett gyümölcsfélék közül, míg a málna, köszméte országos csökkenő tendenciája a megyére is érvényes (Internet13).

Zöldségfélék közül a "hevesi" görögdinnye közismert, melynek termesztése főként Boconád, Csány, Hort településekre koncentrálódik. A hagyományos termesztőkörzetek az ökológiai adottságok, a termesztési tradíciók és az értékesítési lehetőségek alapján jöttek létre. A 19. században dinnye termesztőtájak Csány, Hort, Erdőtelek és Kál településeken alakultak ki. A híres Hevesi tájfajta az 1800-as évek második felében a Csányi tájfajtából szelektált. Azonban a ma népszerú világfajtáktól alacsonyabb termőképessége miatt visszaszorult termesztése. Emellett 
kiemelendő a térség gombatermesztése, mely Kerecsenden létesült, ahol a gombaágazat teljes vertikuma a kutatástól a konzervkészítésig megtalálható (Internet8, 4.-5. kép). A lakosság gombagyűjtése a magasabban fekvő területekről, fôként saját fogyasztásra szintén jellemző.

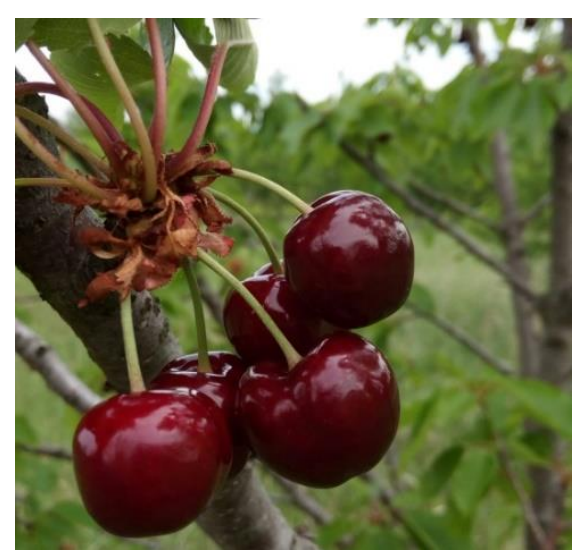

\section{3. kép Szomolyai fekete, rövid szárú cseresznye}

Forrás: Kovácsné, Szomolya, 2017

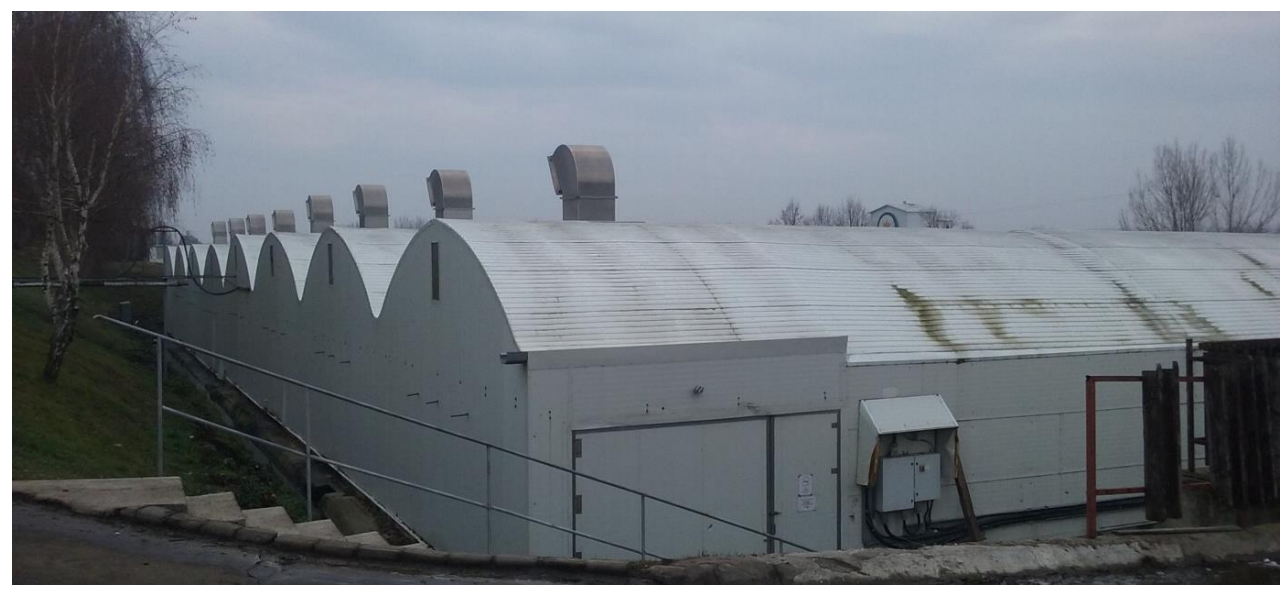

4. kép Korona gombatermesztő üzem

Forrás: Kaprinyáke, Demjén, 2017

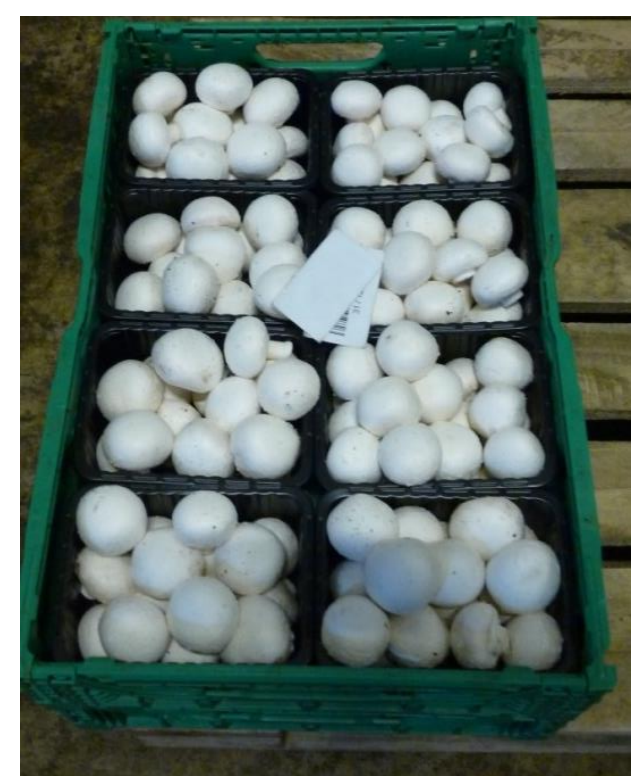

5. kép Frissen szedett fehér csiperkegomba

Forrás. Kaprinyák, Demjén, 2017 


\section{Következtetések}

A mezőgazdaság jelentős ágazat a körzetben, bár 1990 óta a tulajdonosi szerkezet átalakult. A nagyüzemi termesztés megszűnése után magángazdaságok, családi vállalkozások jöttek létre a privatizáció révén, amelyek a korábbitól eltérően leginkább szezonális jelleggel foglalkoztatják a helyi munkaerőt. Az állami támogatás révén megnôtt az új gyümölcs- és szőlőültetvények felülete, valamint a tároló-, feldolgozólétesítmények száma. Mindkettőre a fajtaváltás és az öntözött terület részarányának növekedése jellemző. Azonban a bogyósok közül egyedül a szamóca termőfelülete nem csökkent számottevő módon az utóbbi években, Heves megyében.

A két borvidék (Mátrai, Egri) borelőállítása, -turizmusa terén jelentős fejlesztések történtek. A borutak (Mátrai és Egri borút, szerveződő Felső-magyarországi borút) kialakítása mellett a gasztronómiai rendezvények, fesztiválok lehetnek jó marketing a térség számára (Internet4, Internet7; Internet9). A hungarikumok között olvasható az Egri Bikavér, mely hazánk bortörténelmének első védett eredetű bora (Egri Bikavér Szabályzat, 1997). Egy házasított, terroir vörösborról van szó (6. kép). A Magyar Értéktárban szerepel Eger, Mátra és a velük szomszédos Bükk, boraik folytán. Az Egri bikavér, az Egri Csillag borok és a Szépasszonyvölgy a Heves megyei Értéktárat gazdagítják (Internet7; Internet10; Internet11).

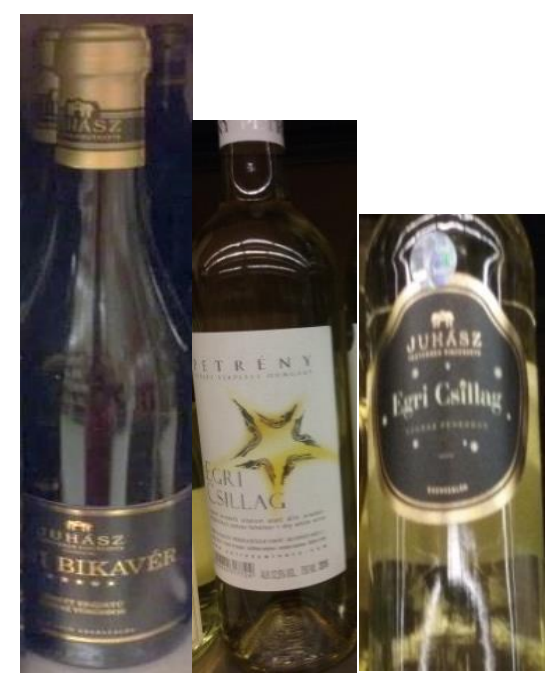

\section{6.-7. kép Egri Bikavér és Egri Csillag \\ Forrás: Kaprinyák, 2018}

\section{Hivatkozott források}

[1.] Baros, Z. - Bujdosó, Z. - Kovács, T. - Patkós, Cs. - Radics, Zs. (2012): The social aspects and public acceptance of biomass giving the example of a Hungarian region International Journal Of Renewable Energy Development, 1(2) 22-30. DOI: 10.14710/ijred.1.2.39-43

[2.] Brózik S. (1959): Termesətett gyümölcsfajtáink 2. Csonthéjastermésúek: Cseresznye - Meggy. Budapest: Mezőgazdasági Kiadó.

[3.] Brózik S. (1960): Termesz̨tett gyümölcsfajtáink 2. Csonthéjastermésüek: Sz̨ilva - Kajsz̨i. Budapest: Mezőgazdasági Kiadó.

[4.] Brózik S. - Kállay T.-né - Apostol J. (2003): Mandula. Budapest: Mezőgazda Kiadó.

[5.] Bujdosó Z. - Remenyik B. (2009): Kereskedelmi vonzáskörzetkutatás elmélete és gyakorlata Heves megyei példákon keresztül In: Pajtókné Tari I. - Tóth A. (szerk.): Változó Föld, változó 
társadalom, változó ismeretszerzés : tudományos konferencia az EKF Földrajz Tanszék 60 éves jubileumához kapcsolódva, Eger: Eszterházy Károly Főiskola, Földrajz Tanszék. pp. 175-180.

[6.] Dóka K. (1982): Gazdálkodás a Tisza árterein a XIX. század első felében. Agrártörténeti S zemle, 24(3-4) 280.

[7.] Dóka K. (1996): Vízépítők, földmérők, útépítôk: mérnökeink a 18. század végétôl a polgári forradalomig. Hidrológiai Közlöny, 76(3-4), 156.

[8.] Harmat L. (szerk.) (1987): Kösæméte. Budapest: Mezőgazdasági Kiadó.

[9.] Kozári J. (1988): Múvelésági és birtokviszonyok Egerben az 1875. évi VII. TC. által létrehozott kataszteri telekkönyv tükrében. Agrártörténeti Szemle, 30(3-4), 458.

[10.] Markos Gy. (1962): Magyarorşág gazdasági földrajza. Budapest: Közgazdasági és Jogi Kiadó.

[11.] Mohácsy M. - Magyar Gy. (1936): Dió-, mandula-, mogyoró- és gesżtenyetermesżtés. Budapest: Pária Nyomda.

[12.] Mohácsy M. - Maliga P. (1956): Cseresznye-és meggytermesztés. Budapest: Mezőgazdasági Kiadó.

[13.] Mohácsy - Porpáczy A. (1951): Dió, mandula, mogyoró, gesztenye. Mezőgazdasági Kiadó, Budapest

[14.] Mohácsy M. - Porpáczy A. (1952): Bogyósgyümölcsüek. Budapest: Mezőgazdasági Kiadó.

[15.] Mohácsy M. - Porpáczy A. - Maliga P. (1957): Gesztenye, mandula, mogyoró. Budapest: Mezőgazdasági Kiadó.

[16.] Nyujtó F. - Surányi D. (1981): Kajsziibarack. Budapest: Mezőgazdasági Kiadó.

[17.] Okályi I. (1954): Gyümölcstermelés I. Budapest: Mezőgazdasági Kiadó.

[18.] Papp J. - Porpáczy A. (1999): Bogyósgyümölcsüek II. Szeder, ribisұ̨ee, kösz̨méte, különleges gyümölcsök. Budapest: Mezőgazda Kiadó.

[19.] Somos A. (1973): A kertészet helyzete és fejlesztésének lehetőségei Heves megyében. Agrártudományi Közlemények (A MTA Agrártudományok Osztályának Közleményei), Akadémiai Kertészeti Nap elóadásai. 32(3-4), 252.

[20.] Surányi D. (2011): Ökológiai szemléletű gyümölcstermesztés - változó termesztő körzetekben. Tájökológiai Lapok 9(2), 321-343.

[21.] Szentiványi P. - Horn E. - Pejovics B. (1976): Dió, gesztenye, mandula, mogyoró. Budapest: Mezőgazdasági Kiadó.

[22.] Internet1: www.hiszi-map.hu/info/magyar/heves/heves-megye.html. Letöltés dátuma: 2021. 10. 25 .

[23.] Internet2: http://www.terport.hu/megyek/magyarorszag-megyei. Letöltés dátuma: 2021. 10. 22.

[24.] Internet3: https://www.arcanum.hu/.../hevesmegye-matrai-resze-platthy-adorjantol-4B3A/. Letöltés dátuma: 2021. 10. 20.

[25.] Internet4: gti.ektf.hu/anyagok/.../heves $\% 20$ megye $\% 20$ fejlesztési $\% 20$ terv $\% 202007$ 2013.pdf: Heves megye területfejlesztési koncepciója és stratégiai programja (2007-2013). Letöltés dátuma: 2021. 10. 22.

[26.] Internet5:elte.pene.hu/5.felev/Magyarorszag\%20tarsadalmi.../Gyumolcstermo_korzeteink.p pt. Letöltés dátuma: 2021. 10. 25.

[27.] Internet6:www.sulinet.hu/oroksegtar/data/.../Egy.../016_Szolo_es_gyumolcsteremeles.htm 1. Letöltés dátuma: 2021. 10. 22.

[28.] Internet7: http://hevesmegye.hu/ertekeink. Letöltés dátuma: 2021. 10. 22.

[29.] Internet8: https://www.agronaplo.hu/.../heves-megye-szolo-es-bor-foldje-hely-ahol-nap-eshegy... Letöltés dátuma: 2021. 10. 25.

[30.] Internet9: http://hevesmegye.hu/hu/gasztronomia. Letöltés dátuma: 2021. 10. 23. 
[31.] Internet10: hungarikum.hu/hu/.../huszonhárom-érték-heves-megyei-értéktárban-bárkiötletelhet. Letöltés dátuma: 2021. 10. 25.

[32.] Internet11:www.hungarikum.hu/sites/default/files/hungarikumok-lista.pdf_Letöltés dátuma: 2021. 10. 20.

[30.] Internet12: https://boraszat.kormany.hu. Letöltés dátuma: 2021. 11. 20.

[31.] Internet13: www.ksh.hu Letöltés dátuma: 2021. 11. 20.

\section{Szerző}

Kaprinyák Tünde

ORCID 0000-0003-1624-9129

$\mathrm{PhD}$

adjunktus

Magyar Agrár- és Élettudományi Egyetem, Károly Róbert Campus, Szőlészeti és Borászati Intézet Kaprinyak.Tunde@uni-mate.hu 